de iones negativos de $\mathrm{H}$ en la colisión con una superficie de HOPG.

The effect of coulombian repulsion between localized electrons in the atom-surface interaction

\section{Summary}

We studied, in this work, the charge exchange between atoms and surfaces involved in the dynamical collision process by using the theoretical frame provided by the Anderson model. The effect of the fine details of the electronic band structure (surface energy gaps, surface states) on the charge exchange process is analyzed within a localized description, and different approximations to the Coulomb repulsion in the atom site are discussed. The projector language is used for introducing the atomic configurations which have an appreciable probability of occurrence in the atom-surface interaction. The dynamical evolution of the interacting system is described by appropriate Green-Keldysh functions, and these ones are solved by means of the Equation of Motion method. The Anderson Hamiltonian parameters are obtained from an ab-initio model calculation that takes into account the chemical properties of the involved atoms.

\title{
Resúmenes de Tesis: Maestría en Didáctica de las Ciencias Experimentales
}

\section{La analogía como estrategia didáctica en la enseñanza del concepto de reactivo limitante y la recuperación de análogos útiles en contenidos de mayor complejidad}

\section{Nancy Silvana Piovano \\ nancypiovano@arnet.com.ar \\ Ester Mercedes Ocampo \\ Facultad de Ingeniería Química \\ Química General \\ Departamento de Química \\ Universidad Nacional del Litoral \\ Fecha de defensa: 04/11/2013}

\section{Resumen}

La problemática que dio origen a esta investigación está fundamentada en la dificultad que presentan los estudiantes universitarios para el aprendizaje de la este- quiometría de reacciones químicas y, en particular, del concepto reactivo limitante. La estequiometría se ocupa de los aspectos cuantitativos de la reacción química por ello es uno de los conceptos centrales de la química. En su aprendizaje los estudiantes presentan dificultades que van más allá de cuestiones matemáticas, como el dominio de la proporcionalidad. El estudio se realizó con alumnos de la asignatura Química de las carreras de Licenciatura en Química, Profesorado en Química y Químico Analista. Una de las primeras unidades del programa de esta asignatura, común a las tres 
carreras, incluye los contenidos mencionados, que no son nuevos para los alumnos, puesto que ya fueron abordados con anterioridad en la escuela media y en cursos preuniversitarios. No obstante, se siguen observando numerosos inconvenientes para su comprensión y aplicación en ejercicios simples o de mayor complejidad.

La persistencia de este problema constituye una preocupación en los profesores, con el agravante de que, aún en asignaturas del ciclo superior, los estudiantes siguen sin poder aplicar estos conceptos correctamente y, en consecuencia, no pueden abordar con eficiencia otros contenidos que están relacionados a ellos.

En ese sentido, el objetivo principal de este trabajo fue indagar acerca de la eficacia de la utilización de una representación analógica para la enseñanza del concepto de reactivo limitante, para luego registrar si los alumnos recuperaban el análogo para resolver ejercicios más complejos, dentro de otra unidad temática del programa. También se plantearon algunos objetivos específicos como: propiciar el intercambio de ideas y el aporte de opiniones entre los actores del proceso didáctico, utilizar el razonamiento analógico para la construcción del concepto reactivo limitante, registrar y discutir analogías autogeneradas por los estudiantes.

El diseño experimental se realizó en concordancia con el paradigma interpretativo. La muestra estuvo compuesta por 60 alumnos de las tres carreras mencionadas. La investigación fue cualitativa y correlacional. Se optó por un esquema cuasiexperimental con postprueba. Previamente se realizó la validación interna y externa del experimento.

En primer lugar el docente utilizó la analogía de Weiner (representación con sándwiches) para explicar los conceptos relacio- nados con estequiometría. En una segunda etapa, se abordó el contenido Sistema Gaseoso, cuya ejercitación involucra cálculos estequiométricos. Una vez terminada la clase, se entregó a los estudiantes un instrumento de resolución individual, que luego se utilizó para evaluar los resultados del experimento. Inmediatamente, se realizaron entrevistas individuales para registrar el mecanismo de razonamiento que habían utilizado los alumnos para la resolución del ejercicio. Por último se efectuó un análisis estadístico con el fin de determinar si las dos variables de interés para esta investigación (resolución correcta del ejercicio y recuperación de la analogía) estaban o no asociadas. Los datos se procesaron con el programa SPSS. A fin de verificar si había asociación significativa entre las variables, se empleó un Test de Hipótesis.

El análisis de los resultados permitió concluir que el $57 \%$ de los alumnos (34) resolvió bien el ejercicio recuperando la analogía con la que habían aprendido. Del $43 \%$ restante, 18 alumnos lo resolvieron exitosamente sin utilizar el razonamiento analógico y sólo 8 no pudieron hacerlo bajo ningún método. El valor del estadístico de Fisher, aplicado a los datos del experimento, demostró que hubo asociación entre las dos variables objeto de estudio, si bien no pudo afirmarse el sentido de esa asociación.

En primer lugar, y a la luz de los resultados, pudo concluirse que la analogía es una herramienta didáctica motivadora para el aprendizaje de conceptos para los que se requiere un grado de abstracción relevante. Los alumnos autogeneraron analogías con éxito y fueron corregidas las erróneas. Se realizó una puesta en común sobre las limitaciones de los análogos seleccionados y sus correspondencias con los conteni- 
dos a aprender. En general, los resultados mostraron que estas estrategias facilitan el aprendizaje de los conceptos: reactivo limitante y estequiometría. Además, esta modalidad de trabajo promueve actividades de metacognición que permiten a los estudiantes reflexionar sobre su forma de abordar el nuevo conocimiento.

The analogy as an instruction tool in the teaching of the concept of limitant reagent and the recovery of useful analogies in more complex contents

\section{Summary}

The problematic that gave rise to this research is based on the difficulty of college students for the learning of the stoichiometry of chemical reactions and, particularly, the concept of limiting reagent. One of the first units of the program of basic chemistry, common to the three careers, includes the mentioned contents, which are not new for the students, since they were already addressed previously in middle school and pre-university courses. The aim of this work was to investigate the effectiveness of the use of an analogy as a teaching strategy for the concept of limiting reagent and stoichiometry, and later, record if students recovered the analog to solve more complex exercises, in the following unit: gaseous state. Other aims were: record and discuss analogies self-generated by students and discuss about metacognition. The experimental design was performed in accordance with the interpretative paradigm. The sample was composed of 60 students. The research was qualitative and correlational. The design consisted of a quasi-experimental with post-test scheme. Previously it was made an internal and external validation of the experiment. The analysis of the results concluded that 57 percent of sample (34) solved exercise correctly recovering the analogy with which they had learned. With respect to $43 \%$ remaining, 18 students solved successfully exercise without the use of analogical reasoning, and only 8 could not do under any method. The value of the statistic of Fisher, applied to experimental data, showed that there was association between studied variables (learning with analogical reasoning and correct resolution of instrument).

\section{Construyendo puentes entre la educación no formal y la enseñanza formal de la Geología}

\author{
María Fernanda Zabalegui \\ fernandazabalegui@hotmail.com \\ Mag.Marcela Manuale \\ Mag. Ana Patricia Fabro \\ Facultad de Bioquímica y Ciencias Biológicas \\ Universidad Nacional del Litoral \\ Fecha de la defensa: 10/10/2013
}

\section{Resumen}

Numerosas investigaciones en el campo de la enseñanza de las Ciencias de la Tierra señalan una notoria ausencia de los contenidos de las mismas en la currícula de la Escuela Secundaria de nuestro país durante las últimas décadas, situación que se está revirtiendo tanto a nivel nacional 